\title{
Variations in Enzyme Activities in Two Sizes of Tilapia guineensis Exposed to Paraquat Dichloride in the Laboratory
}

\author{
*Ukazu, E.R ${ }^{1}$, Chidume, $\mathbf{I}^{2}$ \\ ${ }^{I}$ Fish Technology Department, Nigerian Institute for Oceanography and Marine Research, 3, Wilmot Point \\ Road, Victoria Island, PMB 12729, Lagos - Nigeria \\ ${ }^{2}$ Biotechnology Department, Nigerian Institute for Oceanography and Marine Research, 3, Wilmot Point Road, \\ Victoria Island, PMB 12729, Lagos - Nigeria
}

*Corresponding Author: Ukazu, E.R, Fish Technology Department, Nigerian Institute for Oceanography and Marine Research, 3, Wilmot Point Road, Victoria Island, PMB 12729, Lagos Nigeria

\begin{abstract}
Variations in some enzyme activities in two sizes of Tilapia guineensis exposed to paraquat dichloride in the laboratory were investigated. Two sizes of Tilapia guineensis comprising of 90 each of juveniles (mean total length $12.77 \mathrm{~cm} \pm 3.47 \mathrm{SD}$; mean weight $73.66 \mathrm{~g} \pm 9.55 \mathrm{SD}$ ) and adult (mean total length $18.99 \mathrm{~cm} \pm 8.45 \mathrm{SD}$; mean weight $366.84 \mathrm{~g} \pm 18.56 \mathrm{SD}$ ) were treated to different levels of paraquat concentrations $(0.05 ; 0.10 ; 0.15 ; 0.20 ; 0.25)$ and a control for 15 days. Plasma collected from the fish was analyzed for four different enzymes namely: aspartate transferase (AST), alanine transferase (ALT), alkaline phosphatase (ALP), and acid phosphatase (ACP). The results obtained from the study indicated a concentration dependent increase in all the enzymes above the control value, with a peak at $0.25 \mathrm{mg} / \mathrm{l}$ of the chemical. The study suggests that sublethal level of paraquat concentrations could cause impair enzyme activities in the tissue of the exposed fish. Hence, caution should be applied in the use of this chemical within the vicinity of aquatic environment.
\end{abstract}

Keywords: Fish; Toxicology,Pollution; Biochemistry, Enzymes

\section{INTRODUCTION}

Aquatic pollution is one of the major worldwide environmental issues affecting humanity in recent years [1]. Consequent of industrialization and haphazard urbanization that is prevalent in major cities in the country, many rivers are experiencing convoluted challenges of pollution [2,3]. These have resulted in alarming levels of contamination and environmental degradation, particularly of the aquatic environment [4]. Enzymes play an important role in food utilization and metabolism in a living organism [5]. But this system may get altered under the stress and influence of toxicants [6]. This is because cells in organisms contain enzymes which perform different functions [7]. Conversely, when the integrity of the cell is disrupted through external interference by toxicants, enzymes escape into the plasma in the blood stream where their activities can be measured as a useful tool of cell integrity [8]. The response of aquatic organisms to pollution is expressed through several key biochemical activities involving enzymes which are concerned with the biotransformation system and these biomarkers give early warning signs of aquatic pollution [9].

Evaluation of enzyme activities in the serum or plasma has frequently been used as investigative tool in human medicine all over the world [10]. In addition, enzyme activities have also been comprehensively utilized to predict chemical toxicity especially pesticides in aquatic animals [11]. Moreover, transferases such as alanine aminotransferase (ALT) and aspartate aminotransferase (AST) are liver specific enzymes that give a more insightful appraisal of liver and kidney damage that can be assessed within a short time [14]. However Gabriel et al. [12] reported that alterations in the values of ALT and AST suggest tissue damage in some important organs such as liver, kidney, muscle and gill. Likewise, variations in phospatases, which include alkaline phosphatise (ALP) and acid phosphatise (ACP) activities in tissues, organs and plasma have been reported in fish exposed to toxicants in varying concentrations and have been used as biomarker for tissue damage in fish and a good diagnostic tool in toxicological studies $[13,14.15]$. 
The placid impairment done to a tissue can have significant effect. For instance, mild inflammation to the cells will likely increase the permeability of the cell membrane and allow cytoplasmic enzymes to leak out into the blood, whereas in case of cell necrosis, both cytoplasmic and mitochondrial enzymes will be detected in the blood [16]. Alterations in ALT (Alanine transaminase), ALP (Alkaline phosphatise), AST (Aspartate transaminase) activities of fish resulting from toxicant or contamination effect in various organs of fish have been reported [17, 18]. Such biochemical changes in fish are intended at maintaining equilibrium in the presence of these contaminants, which are known to upset physiological and biochemical processes [19]. According to Das et al., [20], exposure of fish for a long time to most pollutants impede with normal functional metabolism at the cellular level. Decrease in enzyme activities in fish exposed to toxic levels of toxicant could be attributed to either a state of hydration and change in water equilibrium in the fish or a disturbance in some vital organs of the fish[21] Several authors have evaluated the effects of this chemical on fish, but the information on T.guineensis is limited, hence the need for this study.

\section{MATERIALS AND MeTHOdS}

\subsection{Experimental Location and Fish}

The study was carried out in African Regional Aquaculture Center, an outstation of Nigerian Institute for Oceanography and Marine Research, Buguma, Rivers State, Nigeria. A total of 180 T.guineensis comprised of 90 each of juvenile and adult size were sourced from ponds during the low tide. The fishes were transported in four open 501 containers to the laboratory and acclimated for a period of seven days.

\subsection{Preparation of Test Solutions and Exposure of Fish}

Paraquat dichloride used in this experiment was purchased from a commercial outlet in Port Harcourt, Nigeria. T.guineemsis were exposed to the chemical at the concentrations of 0.00 control, 0.05 , $0.10,1.50,0.20$ and $0.25 \mathrm{mg} / \mathrm{L}$ in triplicates. Four fish were randomly distributed into each test tank. The experiment lasted for a period of 15 days. The water in the tanks was renewed daily. The fish were fed twice daily at $3 \%$ body weight with a commercial feed.

\subsection{Analytical Procedure}

At the end of each experimental period, $2 \mathrm{ml}$ of fresh blood sample was collected by making a caudal puncture with the help of fine needle and poured in heparinized sample bottles. Blood samples were centrifuged immediately for 15 minutes at $5000 \mathrm{rpm}$. Plasma specimens were separated, pipetted into eppendorf tubes and stored in a refrigerator at $-20^{\circ} \mathrm{C}$ until assayed [22](Ellman, 1959). The results were read using a universal microplate reader on a Jenway visible spectrophotometer (Model 6405). Five enzymes namely, Aspartate amino transaminase (AST), Alanine amino transaminase (ALT), Alkaline phosphatase (ALP), Acid phosphatase (ACP) and Lactate dehydrogenase (LDH) were analyzed in the blood of the exposed T.guineensis. The Reitman and Frankel[23,24], method was used to analyze AST, because it can be performed as a manual colorimetric end-point technique. While, ALP, ACP and LDH was done by method described by Huang [ [25].

\subsection{Statistical Analysis}

All the data were expressed as mean and standard deviation of mean. The statistical package, SPSS Version 22 was used for the data analysis. The means were separated using two ways ANOVA and the two means were considered significant at $5 \%(\mathrm{P}<0.05)$.

\section{RESULTS}

The water quality parameters (Table 1) were within the same range except in DO, where a lesser values were obtained at higher concentration of the chemical. The effects of paraquat dichloride on the enzymes in the plasma of T.guineensis juveniles are presented in Table 2. It was observed that the values of aspartate transferase (AST), alanine transferase (ALT), alkaline phosphatase (ALP), and acid phosphatase $(\mathrm{ACP})$ significantly $(\mathrm{P}<0.05)$ increased with increasing concentrations of the chemical. The same trends were observed in the enzyme profiles of adult fish exposed to the chemical paraquat dichloride, where all the enzymes under consideration were elevated (Table 3 ). 
Variations in Enzyme Activities in Two Sizes of Tilapia guineensis Exposed to Paraquat Dichloride in the Laboratory

Table1. Physico-Chemical Parameters of Water in Experimental Tanks of T. guineensis Treated with Paraquat

\begin{tabular}{|l|l|l|l|l|}
\hline Concentration & $\mathbf{D O}(\mathbf{m g} / \mathbf{l})$ & Temperature $\left({ }^{\mathbf{o}} \mathbf{C}\right)$ & $\mathbf{p H}$ & $\mathbf{N H 3}(\mathbf{m g} / \mathbf{l})$ \\
\hline 0.00 & $5.95 \pm 0.47^{\mathrm{b}}$ & $29.99 \pm 3.01^{\mathrm{a}}$ & $6.51 \pm 1.02^{\mathrm{a}}$ & $0.02 \pm 0.00^{\mathrm{a}}$ \\
\hline 0.05 & $5.71 \pm 0.31^{\mathrm{b}}$ & $29.67 \pm 3.93^{\mathrm{a}}$ & $6.24 \pm 1.99^{\mathrm{a}}$ & $0.02 \pm 0.00^{\mathrm{a}}$ \\
\hline 0.10 & $5.47 \pm 0.52^{\mathrm{b}}$ & $29.07 \pm 1.52^{\mathrm{a}}$ & $6.73 \pm 1.75^{\mathrm{a}}$ & $0.02 \pm 0.00^{\mathrm{a}}$ \\
\hline 0.15 & $5.07 \pm 0.55^{\mathrm{b}}$ & $29.87 \pm 2.56^{\mathrm{a}}$ & $6.49 \pm 1.99^{\mathrm{a}}$ & $0.02 \pm 0.00^{\mathrm{a}}$ \\
\hline 0.20 & $4.37 \pm 0.65^{\mathrm{a}}$ & $29.61 \pm 3.05^{\mathrm{a}}$ & $6.71 \pm 1.72^{\mathrm{a}}$ & $0.03 \pm 0.00^{\mathrm{a}}$ \\
\hline 0.25 & $4.01 \pm 0.91^{\mathrm{a}}$ & $29.77 \pm 2.06^{\mathrm{a}}$ & $6.52 \pm 1.89^{\mathrm{a}}$ & $0.03 \pm 0.00^{\mathrm{a}}$ \\
\hline
\end{tabular}

Means within the same column with different super scripts are significantly different $(P<0.05)$

Table2. Variations in Enzymes Activities in T. guineensis Juveniles Exposed to Paraquat Dichloride

\begin{tabular}{|l|l|l|l|l|}
\hline \multirow{2}{*}{$\begin{array}{c}\text { Concentrations } \\
(\mathbf{m g} / \mathbf{L})\end{array}$} & \multirow{3}{|c|}{ Enzymes (IU/L) } \\
\cline { 3 - 5 } & AST & ALT & ACP & ALP \\
\hline 0.00 & $60.77 \pm 3.88^{\mathrm{a}}$ & $48.88 \pm 2.90^{\mathrm{a}}$ & $25.68 \pm 6.50^{\mathrm{a}}$ & $54.92 \pm 7.69^{\mathrm{a}}$ \\
\hline 0.05 & $69.43 \pm 5.71^{\mathrm{a}}$ & $58.66 \pm 7.91^{\mathrm{a}}$ & $27.90 \pm 7.23^{\mathrm{a}}$ & $56.78 \pm 7.92^{\mathrm{a}}$ \\
\hline 0.10 & $75.61 \pm 4.57^{\mathrm{b}}$ & $69.90 \pm 5.07^{\mathrm{b}}$ & $32.37 \pm 5.93^{\mathrm{b}}$ & $65.77 \pm 8.92^{\mathrm{b}}$ \\
\hline 0.15 & $77.69 \pm 2.88^{\mathrm{b}}$ & $79.77 \pm 6.82^{\mathrm{b}}$ & $33.95 \pm 3.66^{\mathrm{b}}$ & $67.66 \pm 8.83^{\mathrm{b}}$ \\
\hline 0.20 & $82.46 \pm 3.17^{\mathrm{b}}$ & $82.62 \pm 6.46^{\mathrm{c}}$ & $35.66 \pm 5.58^{\mathrm{b}}$ & $74.88 \pm 9.81^{\mathrm{c}}$ \\
\hline 0.25 & $94.99 \pm 7.66^{\mathrm{c}}$ & $86.08 \pm 8.72^{\mathrm{c}}$ & $49.92 \pm 8.44^{\mathrm{c}}$ & $89.69 \pm 7.01^{\mathrm{a}}$ \\
\hline
\end{tabular}

Means within the same column with different super scripts are significantly different $(P<0.05)$

Table3. Enzymes Activities in T. guineensis Adults Exposed to Paraquat Dichloride

\begin{tabular}{|l|l|l|l|l|}
\hline \multirow{2}{*}{ Concentration } & \multirow{2}{*}{} & \multicolumn{3}{|c|}{ Enzymes (IU/L) } \\
\cline { 3 - 5 } & AST & ALT & ACP & ALP \\
\hline 0.00 & $70.24 \pm 5.90^{\mathrm{a}}$ & $65.00 \pm 9.05^{\mathrm{a}}$ & $35.88 \pm 7.71^{\mathrm{a}}$ & $66.38 \pm 8.19^{\mathrm{a}}$ \\
\hline 0.05 & $84.65 \pm 6.07^{\mathrm{b}}$ & $68.66 \pm 9.62^{\mathrm{a}}$ & $40.88 \pm 8.72^{\mathrm{b}}$ & $78.54 \pm 7.04^{\mathrm{a}}$ \\
\hline 0.10 & $89.81 \pm 2.80^{\mathrm{b}}$ & $69.33 \pm 8.82^{\mathrm{a}}$ & $45.81 \pm 7.91^{\mathrm{b}}$ & $87.94 \pm 9.82^{\mathrm{b}}$ \\
\hline 0.15 & $91.81 \pm 8.41^{\mathrm{c}}$ & $76.00 \pm 9.02^{\mathrm{b}}$ & $47.90 \pm 8.08^{\mathrm{b}}$ & $85.32 \pm 8.77^{\mathrm{b}}$ \\
\hline 0.20 & $98.98 \pm 4.91^{\mathrm{c}}$ & $81.00 \pm 7.05^{\mathrm{c}}$ & $54.28 \pm 7.69^{\mathrm{c}}$ & $82.09 \pm 7.51^{\mathrm{b}}$ \\
\hline 0.25 & $116.88 \pm 9.72^{\mathrm{d}}$ & $95.66 \pm 8.88^{\mathrm{c}}$ & $66.92 \pm 7.05^{\mathrm{c}}$ & $103.33 \pm 9.09^{\mathrm{c}}$ \\
\hline
\end{tabular}

Means within the same row with different super scripts are significantly different $(P<0.05)$

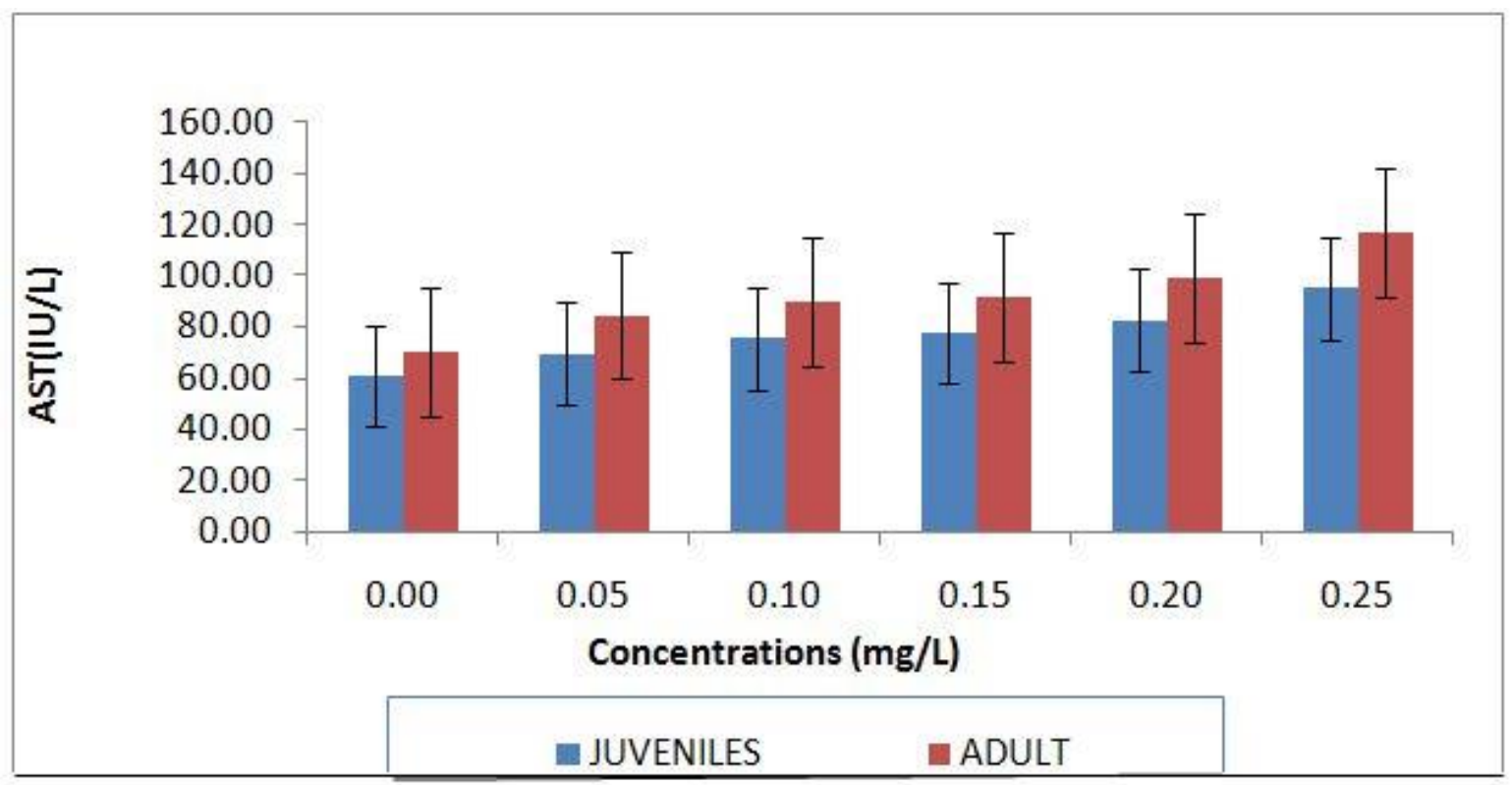

Figure1. Comparative Values of AST in the Plasma of T.guineensis Exposed to Paraquat 


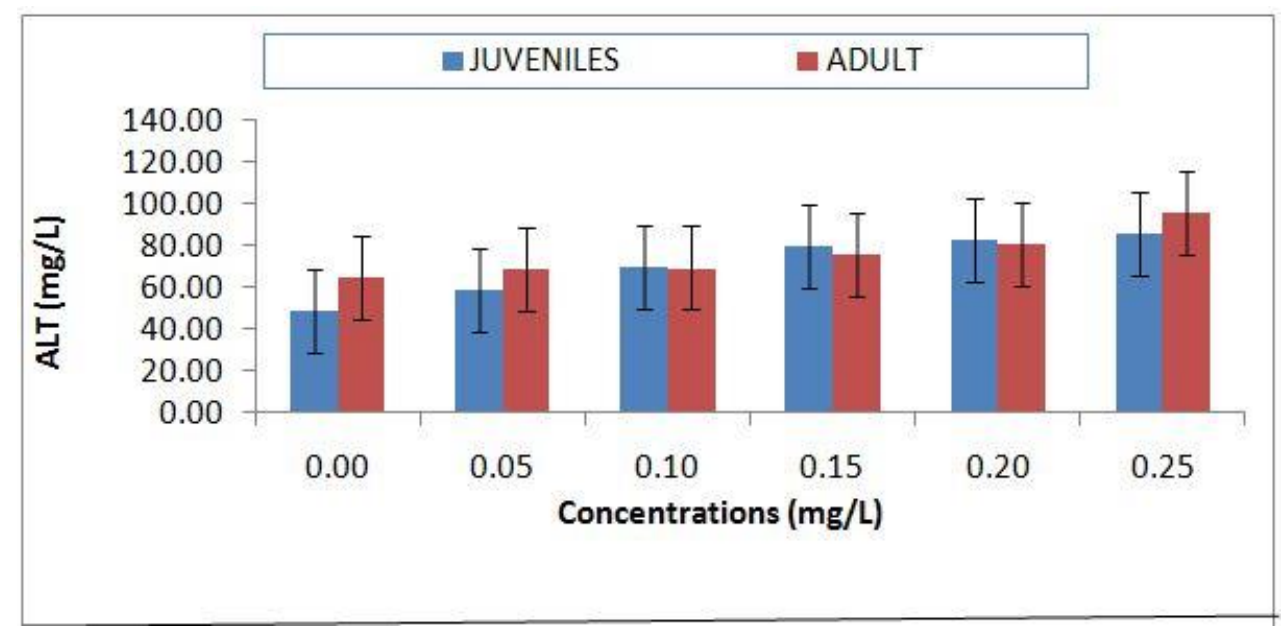

Figure2. Comparative Values of ALT in the Plasma of T.guineensis Exposed to Paraquat

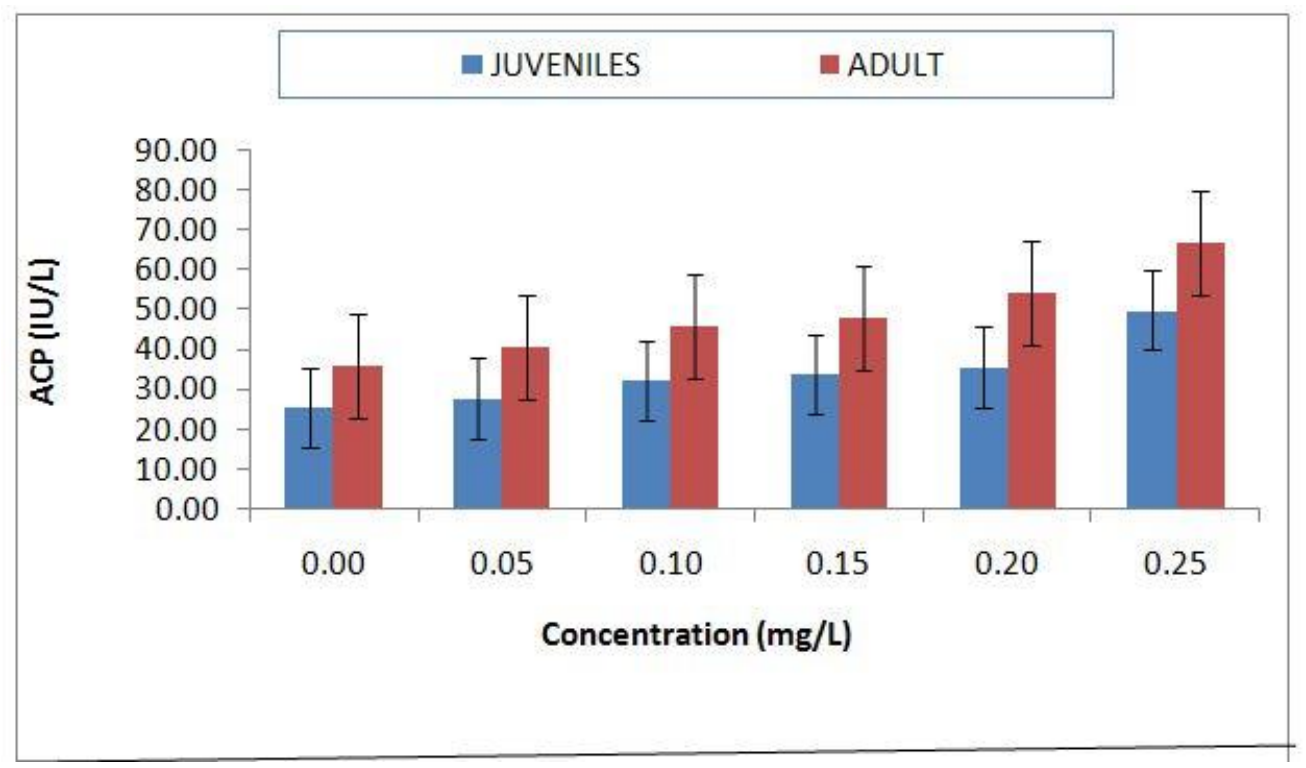

Figure3. Comparative Values of ACP in the Plasma of T.guineensis Exposed to Paraquat

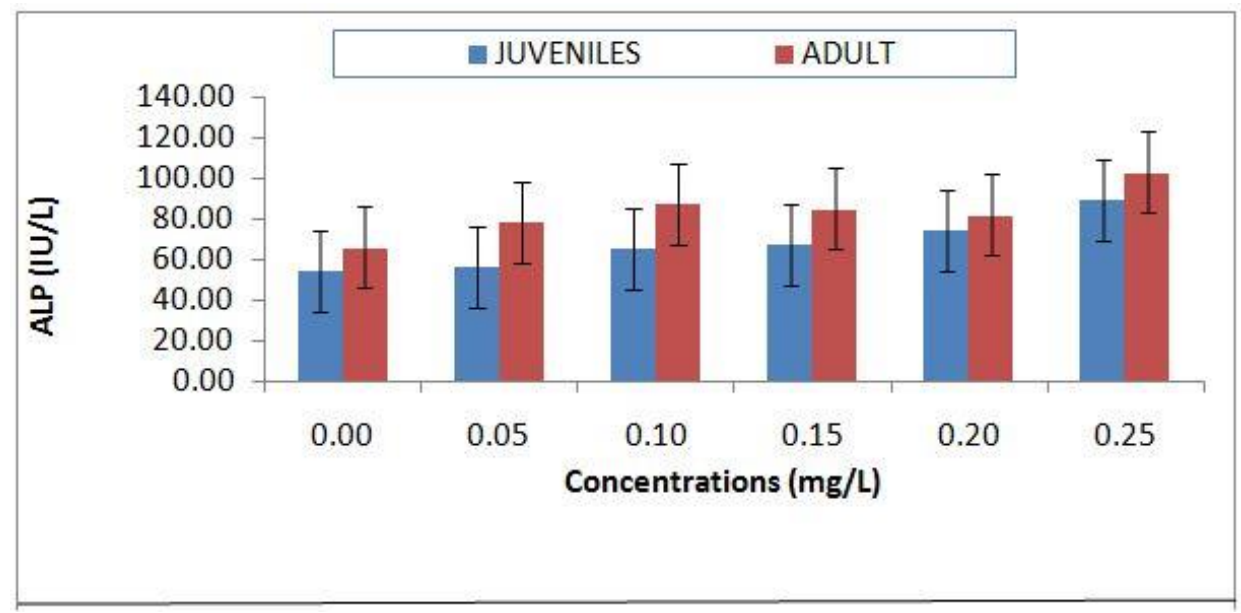

Figure4. Comparative Values of ALP in the Plasma of T.guineensis Exposed to Paraquat

\section{DISCUSSION}

Water quality parameters such as temperature, dissolved oxygen, $\mathrm{pH}$, and ammonia evaluated in this study are critical and influence fish health, growth and reproduction in the aquatic medium [26]. The values of the parameters were within the same range except dissolved oxygen that reduced with 
increasing concentrations of the chemical. This results agrees with the findings of Alalibo et al. [27], in the experimental water of T.guineensis exposed to dimethoate. In this study, enzymes assays such as ALP, AST, ALT, and ACP are parts of routine laboratory analysis tests to identify anomaly in the physiological status of aquatic in animals [28]. Alterations in any of these enzymes resulting from pollutants consequence in the plasma of fish have been reported by various authors [29-31]. Such alterations in fish are aimed at maintaining equilibrium in the presence of these toxicants which are known to disrupt physiological and biochemical processes [32].

In this study, activities of these enzymes increased, as the concentration of paraquat increased in the plasma of the exposed fish, This results agrees with the report of Das et al. in Indian major carps exposed to nitrite toxicity [33]. They suggested that the increase of transferases is as a result of diversion of alpha-amino acids in the tricarboxylic acid (TCA) cycle as keto-acids to augment energy production in the cell of the fish. Moreover, cellular toxicity of organophosphates have been attributed to an increase in AST, ALT and ALP in the plasma of Sarotherodon melanotheron exposed to industrial effluents [34]. In this study AST activity was elevated in the plasma of the exposed fish probably to enable the fish cope with the energy demand during stress condition. Similar findings, suggest that this energy demand could be satisfied through amino acid. ALP activity [35].

In this work, ALT and ACP activities increased in T.guineensis exposed to paraquat, an increase these enzymes is an indications that some vital organs of the fish have been impaired [36]. This view was supported by Gabriel et al. [36] when $C$. gariepinus was exposed to cypermethrin in the laboratory. ALT activity reflects a change in endoplasmic reticulum mass; it is also known to occur in the cell membrane and may be involved in metabolic activities [37]. This increase may denote an increase in metabolic transport] which may eventually result in a shift in biosynthesis and the energy metabolism pathway of the exposed organism [38]. While an elevation in ACP, as observed in this study suggests an increase in lysosomal mobilization and cell necrosis due to effluent toxicity [39].

\section{CONCLusions}

This study revealed that exposure of T.guineensis to sublethal levels of paraquat dichloride produced significant changes in the physiology composition of the fish as revealed by alterations in the enzyme activities in this study. Continual $t$ exposure through pollution by the pesticides in aquatic environments can lead to mortality of T.guineensis and economic loss. Adequate disposal of pesticides is hereby advocated to prevent ecological challenges in the aquatic medium.

\section{REFERENCES}

[1] Adewoye S.O, Fawole O.O, Owolabi O.D, Omotosho J.S (2005) Toxicity of cassava waste water effluents of African Catfish: Clarias gariepinus. Ethiop J Sci 28: 189-194.

[2] Ayoola SO (2008) Toxicity of glyphosphate herbicide on Nile tilapia (Oreochromis niloticus) juvenile. Agric Res 3: 825-834.

[3] Gabriel, U.U., Akinrotimi, O.A and Eseimokumo, F. (2011).Haematological responses of wild Nile tilapia (Oreochromis niloticus) after acclimation to captivity. Jordan Journal of Biological Sciences, 4: 223230 .

[4] Nte, M.E, Edun O.M and Akinrotimi O.A. (2018). Behavioural Responses in Mudskipper (Periopthalmus Papilio) Exposed to Sodium Bromide under Laboratory Conditions. International Journal of Poultry and Fisheries Sciences, 2(1),1-7.

[5] Gabriel U, George ADI (2005) Plasma enzymes in Clarias gariepinus exposed to chronic levels of roundup (glyphosate). Environmental Ecology, 25:271-276.

[6] Abbas, H.H.H (1998). Toxicological Effect of Copper and Lead on some aspects in two Fish species,Blue Tilapia (Oreochromis niloticus) and African Catfish (Clarias gariepinus).PhD Thesis, Faculty of Science, Cairo University, Egypt. 321pp.

[7] Nte, M.D., Hart, A.I., Edun, O.M., and Akinrotimi, O.A. (2011). Alterations in enzymes activities as a biomarker in blackjaw tilapia (Sarotherodon melanotehron) exposed to industrial effluents. Continental Journal of Biological Science,4(2):37-44.

[8] Anderson, T, Forlin, L, Hardig J, and Larsson, A (1988). Physiological disturbances in fish living in Coastal water polluted with bleached Kraft pulp mill effluents. Canadian Journal of Fisheries and Aquaculture Sciences, 45:1525-1536. 
[9] Celik, E.S. (2004). Blood chemistry (electrolytes, lipoproteins and enzymes) values of black scorpion fish (Scorpaena porcus) in the Dardanelles. Turkey Journal of Biological Sciences, 4:716-719.

[10] Ogundiran, M.A, Fawole O.O, Adewoye S.O and Ayandiran T.A (2009) Pathologic Lesions in the Gills structures of Clarias gariepinus on exposure to sub-lethal concentrations of soap and detergent effluents. Journal of Cell and Animal Biology, 3: 078-082.

[11] Ogamba, E.N., I.K.E.Ekweozor and E.R. Daka (2005). The influence of human activities on the zooplankton of Elechi Creeck Complex in the Niger Delta. Africa J. Environment Pollut. Health, 4 ()2): 31 -38 .

[12] Gabriel, U.U, Akinrotimi, O.A and Ariweriokuma, V.S.(2012). Changes in metabolic enzymes activities in selected organs and tissues of Clarias gariepinus exposed to cypermethrim. Journal of Chemical Engineering, 1(1): 25 -30.

[13] Tamas, L., Huttova, Jand Mistrik, L. (2002). Effect of carboxymethyl chitin-glucan on activity of hydrolytic enzymes. Chemical Pathology, 56: 326-329.

[14] Tiwari, S and Singh, A. (2004). Piscidal activity of alcohol extract of Nerium indicum leaf and their biochemical stress response on fish metabolism. African Journal of Traditional Medicine,4: 15-29.

[15] Van der Oost, R., Beyer, J and Vermulen, N.P.E. (2003). Fish bioaccumulation and biomarker environmental risk assessment a review. Environmental Toxicology and Pharmacology, 13: 57-149.

[16] Inyang, I.R., Akio, K. and Izah, S.C. 2016c. Effect of dimethoate on lactate dehydrogenase, creatinine kinase and amylase in Clarias lazera. Biotechnological Research, 2(4): 155- 160.

[17] Adedeji, O.B, Adeyemo O.K, Agbede S.A. (2009). Effects of diazinon on blood parameters in the African catfish (Clarias gariepinus). African Journal of Biotechnology, 8: 3940-3946.

[18] Hadi A, Shoker A, Alwan S (2009). Effect of aluminium on the biochemical parameters of fresh water fish Tilapia zillii. J Sci Appl 3: 33-41

[19] Manoj, K (1999) Mercury, copper and cadmium induced changes in the total protein levels of muscle tissue of edible estuarine fish (Boleopthalmus dessumuri). Cuv J Env Bio 20: 231-234.

[20] Alkahem H.F, Ahmed Z, Al-Akel AS, Shansi M.J.K (1998). Toxicity bioassay and changes in haematological parameters of Oreochromis niloticus induced by trichloroform. Arab Gulf J Sci Res 16: 581-585.

[21] Cech JJ, Bartholow SD, Young PS, Hopkins TE (1996) Striped bass exercise and handling stress in fresh water: Physiological responses to recovery environment. Trans Am Fish Soc 125: 308-320.

[22] Begum, G. (2004). Carbofuran insecticide induced biochemical alterations in liver and muscle tissues of the fish Clarias batrachus (linn) and recovery response. Aquatic Toxicology, 66: 83-92.

[23] Reitman ,S and Frankel, F.A.J. (1957). Colorimetric method for determination of serum Got and Gpt activity. Wiener Lab. 2000-Rosario-Argentina,.41pp.

[24] Bessey, M.M., Benfey, T.J and Kieffer, J.D. (2010). Haematology and stress physiology of juvenile diploid and triploid short nose sturgeon (Acipenser brevirostrum). Fish Physiology and Biochemistry, 31: 303-313.

[25] Huang, C., Chao, L.C., and Lin, H.A. (2010). Na+, k+ AT pase and vacuolar-type H+-AT pase in the gill of the aquatic air breathing fish (Trichogaster microlepis) in response to salinity variation. Comparative Biochemistry Physiology, 155: 309-318.

[26] Gabriel, U.U., Akinrotimi, O.A., \& Ariweriokuma, S.V. (2012). Alterations of selected electrolytes in organs of African catfish, Clarias gariepinus treated with cypermethrin. Advances in students Research, 2(1),53-60.

[27] Alalibo, O.O., Gabriel, U.U.,Edun, O.M \& Akinrotimi O.A. (2019). Variations in Some Electrolytes in Tilapia guineensis Exposed to Dimethoate (DMC) International Journal of Innovative Studies in Aquatic Biology and Fisheries 5(4), 12-15.

[28] Gabriel, U.U., Akinrotimi, O.A and Eseimokumo, F. (2011).Haematological responses of wild Nile tilapia (Oreochromis niloticus) after acclimation to captivity. Jordan Journal of Biological Sciences, 4: 223230.

[29] Nte, M.D., Hart, A.I., Edun, O.M., and Akinrotimi, O.A. (2011). Alterations in enzymes activities as a biomarker in blackjaw tilapia (Sarotherodon melanotehron) exposed to industrial effluents. Continental Journal of Biological Science,4(2):37-44.

[30] Ogundiran, M.A, Fawole O.O, Adewoye S.O and Ayandiran T.A (2009) Pathologic Lesions in the Gills structures of Clarias gariepinus on exposure to sub-lethal concentrations of soap and detergent effluents. Journal of Cell and Animal Biology, 3: 078-082. 
[31] Luskova, V., Svoboda, Mand Kolarova J (2002). The effects of diazinon on blood plasma biochemistry in carp (Cyprinus carpio). Acta Vetrinary Brno 71:117-123.

[32] Jha A.G, Mekkawyl A.A, Verreth J, Kirschbaum F (2007) Effects of lead nitrate on the activity of metabolic enzymes during early developmental stages of the African Catfish. Clarias gariepinus (Burchell, 1822) Fish Physiol Biochem 33: 1-13.

[33] Das, P.C., Ayyappan, S., Das, B.K., and Jena, J.K. (2004). Nitrite toxicity in Indian major carps: sublethal effect on selected enzymes in fingerlings of Catla catla,Labeo rohita, and Cirrhinus mrigala. Comparative Biochemistry and Physiology, 138: 3 -1011.

[34] Nte, M.E., Edun, O.M and Akinrotimi O.A. (2018).Biochemical Changes in Mudskipper (Periophthalmuspapilio) exposed to sodium bromide. International Journal of Advanced Research in Medical \& Pharmaceutical Sciences (IJARMPS-ISSN-2455-6998) 3(2)1-6.

[35] Begum, G. (2004). Carbofuran insecticide induced biochemical alterations in liver and muscle tissues of the fish Clarias batrachus (linn) and recovery response. Aquatic Toxicology, 66: 83-92.

[36] Gabriel, U.U, Akinrotimi, O.A and Ariweriokuma, V.S.(2012). Changes in metabolic enzymes activities in selected organs and tissues of Clarias gariepinus exposed to cypermethrim. Journal of Chemical Engineering, 1(1): 25 -30.

[37] Tamas, L., Huttova, Jand Mistrik, L. (2002). Effect of carboxymethyl chitin-glucan on activity of hydrolytic enzymes. Chemical Pathology, 56: 326-329.

[38] Tiwari, S and Singh, A. (2004). Piscidal activity of alcohol extract of Nerium indicum leaf and their biochemical stress response on fish metabolism. African Journal of Traditional Medicine,4: 15-29.

[39] Van der Oost, R., Beyer, J and Vermulen, N.P.E. (2003). Fish bioaccumulation and biomarker environmental risk assessment a review. Environmental Toxicology and Pharmacology, 13: 57-149

Citation: Ukazu, E.R \& Chidume, I" Variations in Enzyme Activities in Two Sizes of Tilapia guineensis Exposed to Paraquat Dichloride in the Laboratory", International Journal of Innovative Studies in Aquatic Biology and Fisheries (IJISABF), vol. 7, no.1, pp. 31-37, 2021. http://dx.doi.org/10.20431/24547670.0701005

Copyright: () 2021 Authors. This is an open-access article distributed under the terms of the Creative Commons Attribution License, which permits unrestricted use, distribution, and reproduction in any medium, provided the original author and source are credited. 